\title{
Studies on Ichthyofaunal Diversity of Temar River, Jabalpur, Madhya Pradesh, India
}

\author{
Chanchala Shiv ${ }^{1}$, R. K. Shrivastava ${ }^{2}$, K. K. Dube ${ }^{3}$ \\ ${ }^{1,2}$ Environmental Research Laboratory, P.G. Department of Environmental Science, Govt. Model Science College (Autonomous), Jabalpur \\ 482001 (M.P.) India
}

${ }^{3}$ Department of Zoology, Govt. Model Science College (Autonomous), Jabalpur 482001 (M.P.) India

\begin{abstract}
The fishes are one of the most important vertebrate, provide rich protein sources for human and several animals and important elements in the economy of many countries. Fish diversity of river essentially represents the fish faunal diversity and their abundance. Rivers conserve a rich variety of fish species which supports the commercial fisheries. The country is rich in diversity of such important group of animals. Keeping in the view, the diversity of fish fauna of the Temar River in Jabalpur District, Madhya Pradesh, India, has been studied form the period November 2013 to October 2014. The aim of the study was to explore the fish fauna of Temar River in the course of investigation, three sampling site were selected viz. Near Temar Bridge, Near Temar Fall and Near Saliwara village, Jabalpur. The total 34 fish species were recorded under 7 order and 11 families. 2 species of Clupiformes, 16 species of Cypriniformes, 8 species of Siluriformes, 1 species of Beloniformes, 3 species Ophiocephaliformes, 2 species of Perciformes and 2 species of Masta cembeliformes have been recorded. The Cyprinidae family is dominant followed by Bagridae and Ophiocephalidae. Recently, the Tor tor fish species commonly called "Mahasheer" has been declared state Fish of Madhya Pra desh. The over fishing and pollution are the major threat for fish diversity of the Temar River.
\end{abstract}

Keywords: Fish diversity, Fresh Water Fishes, Temar River, Jabalpur, Madhya Pradesh

\section{Introduction}

Fish constitutes half of the total number of vertebrates in the world. They live in almost all conceivable aquatic habitats; 21,723 living species of fish have been recorded out of 39,900 species of vertebrates, 8,411 are freshwater species and 11,650 are marine. India is one of the mega biodiversity countries in the world and occupies the ninth position in terms of freshwater mega biodiversity. India are 2,500 species of fishes of which 930 live in freshwater and 1,570 are marine [1].

River Temar touches Jabalpur. It originates from Palatwara village near Ghansore, district Seoni M.P. It joins Narmada River near Saliwara village, Bargi, district Jabalpur M.P. The river is the lifeline of the people resides in nearby villages mostly for various domestic activities. The peoples are catching, selling and feeding the fishes form the Temar River. The diversity of the river is still unexplored and not documented. The fresh water fishes are well studied and documented across the country [2-4].

Several renowned workers studied the fresh water fishes of rivers, ponds, lakes, dams and reservoir of the country. The fish fauna of Madhya Pradesh and Jabalpur was studied Hora [5, 6], Hora and Nair [7], Swarup [8], Dubey and Mehra [9], Soni [10, 11], Malviya [12], Dubey and Verma [13], Mathur and Mishra [14], Tilak and Sinha [15], Karmakar and Datta [16], Saxena [17], Desai [18], Desai et al. [19], Sen [20, 21], Sharma [22-24], Dwivedi et al. [25], Shukla et al. [26], Chandra et al. [27], Thilak [28, 29], Mahor [30] and Solanki et al. [31]. However, data on the fish fauna of Madhya Pradesh have limitations as most of the rivers have not surveyed extensively and checklists for individual rivers are not available. In the present study, we document the fish fauna of Temar River, Jabalpur District, Madhya Pradesh.

\section{Materials and Methods}

The Temar River is one of the most important river of Jabalpur and Seoni District of Madhya Pradesh. In the present study the Ichthyofaunal diversity of Temar River, was studied at three sampling site, these are Near Temar Bridge, Near Temar Fall, Near Saliwara village. The area enjoys semi-arid type of climate with mean annual precipitation of $1358 \mathrm{~mm}$. Fishes were collected form Temar River Near Temar Bridge, Near Temar Fall, Near Saliwara village. Fish were collected in three seasons (pre monsoon from February to May, monsoon from June to September and post monsoon form October to January) for a period of one year from November 2013 to October 2014. The fishes were collected by hand-net, cast nets (Ghagaria Jaal), local fisherman and local markets. Collected fish samples were preserved in $10 \%$ formalin solution and systematic indentified following Talwar and Jhingran [32], Jayaram [33], Day [34] and Shrivastava [35].

Visual observation were also carried out if the water was clear, to understand the distribution of fish species. The relative abundance of the fish was classified into four categories namely abundant $(76-100 \%$ of total catch), Common $(51-75 \%$ of the total catch), moderate $(26-50 \%$ of the total catch) and rare (1-25\% of the total catch), assuming the fishing efforts constant for each catch. Threat status was determined as previously reported by Molur and Walker [3].

\section{Result and Discussion}

During the study, total 34 species of primary freshwater fishes belonging to 7 orders, 11 families and 19 genera were recorded from the study sites. Number of species, their distribution in different study sites, threat status and relative abundance is given in Table, 1 . Maximum number of species and individuals were recorded in sampling site-3 (Near 


\section{International Journal of Science and Research (IJSR) \\ ISSN (Online): 2319-7064}

Index Copernicus Value (2015): 78.96 | Impact Factor (2015): 6.391

Saliwara Village) whereas low number of species and individuals were recorded in sampling site-1 (Near Temar Bridge). In the assemblage structure, cyprinid constituted the dominant group and the cyprinids Catla catla, Cirrhinus mrigala, Cyprinus carpio, Labeo rohita, Osteobrama cotio, Puntius sarana, Puntius sophore, Puntius ticto and Tor tor are represented in all study sites. The Cyprinids Labeo bata and Puntius chola represents only single location (Near Saliwara Village). In all 4 species these are Labeo bata, Puntius chola, Channa striatus, Anabas testudineus represents only single site (Near Saliwara Village) whereas 24 Fish species are recorded in all study sites and 6 Fish species there are Cirrhinus reba, Ctenopharyngodon idellus, Labeo calbasu, Labeo fimbriatus, Labeo gonius, Xenentodon cancila absent only single site (Near Temar Bridge). The family Cyprinidae dominated with 16 species followed by Bagridae with 4 species and Ophiocephalidae with 3 species besides other families as Notopteridae, Siluridae, Mastacembelidae with 2 species and Clariidae, Heteropneustidae, Belonidae, Nandidae, Anabantidae with 1 species. (Table 1). The Mahasheer, Tor tor, an endangered and highly prized sport fish is abundant and thriving well in all the three study sites and has been declared as state fish of Madhya Pradesh.

Out of the 34 species, 2 species Tor tor and Ompok bimaculatus are endangered, 8 species vulnerable, 18 species are lower risk near threatened, 1 species lower risk least concern, 2 species are exotic and 3 species are not evaluated categories (Molur and Walker [3]).

\section{Conclusion}

The study revealed that many species in the study area are being threatened by various human activities, invasive alien species and destructive fishing. Moreover, removal of sewage runoff into the river causes severe threats to fish diversity. Special attention is to be given for conservation of these fish diversity. The observations recorded in the present study may prove valuable as a reference for assessing the changes due to the environmental conditions in the locality, in future. The findings of the present study underline the importance of Temar River in providing preferred abode for fishes.

\section{Acknowledgement}

We are thankful to the Head, Department of Environmental science, Govt. Model Science College, Jabalpur (M.P.) for providing the necessary laboratory facilities and Dr. R.K. Shrivastava Prof. (Environmental Science) Dr. K.K. Dube, Professor of Zoology (Retd.) Govt. Model Science College, Jabalpur (M.P.) for their help in work of laboratory and identification of some fishes.

\section{References}

[1] Kar, D.A., C. Kumar, Bohra and L.K. Singh, (Eds), 2003. Fishes of Barak drainage, Mizoram and Tripura; In: Environment, pollution and management, $\mathrm{APH}$ publishing corporation, New Delhi, pp: 604: 203-211.
[2] Jayaram, K.C., 2010. The freshwater fishes of the Indian region. Narendra Publishing House, Delhi, pp: 614.

[3] Molur, S. and. Walker, S., 1998. Report of the Conservation Assessment and Management Plan. Workshop on freshwater fishes of India. Zoo Outreach Organization/ CBSG, Coimbatore, India, pp: 156.

[4] Daniels, R.J., 2001. Endemic fishes of the Western Ghats and the Satpura Hypothesis. Current Science, 81(3): 240-244.

[5] Hora, S.L., 1938. Notes on fishes in the Indian Museum. On a collection of fish Bailadila range, Baster State, Central Provinces, Record of Indian Museum, 40(3): 237-241.

[6] Hora, S.L., 1940. On a collection of fish from the hard water of the Mahanadi River, Raipur district, C.P. Record of Indian Museum, 42(2): 365-375.

[7] Hora, S.L., and Nair, K.K., 1941. Fishesh of the Satpura Range, Hoshangabad District, Central Provinces. Record of Indian Museum, 43(3): 361-373.

[8] Swarup, H., 1953. Fish fauna of Sagar Lake. Sagar University Journal, 1(2): 239-244.

[9] Dubey, G.P. and R Mehra,.K., 1959. Fish and fisheries of Chambal River. Proc. First All India Congress in Zoology, pp: 647-664.

[10] Soni, D.D., 1959. Fish fauna of Bhopal Lower Lake. Proc. Proc. First All India Congress in Zoology, pp: 639-641.

[11] Soni, D.D., 1960. Fish fauna of Bhopal Upper Lake. Proc. Indian Science, 47(3): 477.

[12] Malviya, R.B., 1961. A list of fishes from Jabalpur, M.P. Proc. National Academy of Science India Section B, 31(3): 349-354.

[13]Dubey G.P. and Verma, M.N., 1965. A preliminary study of the fish fauna of Madhya Pradesh. The Vikram, Journal of Vikram University, 8(4): 1-8.

[14] Mathur, D.S. and Mishra, S.K., 1976. Addition to the fish fauna of Jabalpur district (M.P.). Newsletter of Zoological Survey of India, 2 (4): 156-158.

[15] Tilak, R. and Sinha, N.K., 1979. A checklist of fishes from Madhya Pradesh (India). Zoological of Systematic, 106: 175-196.

[16] Karmakar, A.K. and Datta, A.K., 1988. On a collection of fish from Bastar District, Madhya Pradesh. Record of Zoological Survey of India Occasional Paper, 98: 1-50.

[17] Saxena, R. M., 1988. A checklist of fishes of Rewa District, Madhya Pradesh (India). Cheetal, 29(1): 40-50.

[18]Desai, V.R. 1994. Endangered, vulnerable and rare fishes of river systems (Western and Central) of Madhya Pradesh. Threatened fishes of India. Nature conservation Publication, 4: 97-108.

[19] Desai, V.R., Kumar D. and Shrivastava,N.P., 1997. Fish fauna of Ravishankar Sagar Reservoir. Journal of Inland Fisheries Society of India, 29(2): 53-56.

[20] Sen, T.K., 1995a. Fauna of Indravati Tiger Reserve, Conservation Area Series, Zoological Survey of India, 6: $61-70$.

[21] Sen, T.K., 1995b. Fauna of Kanha Tiger Reserve, Conservation Area Series, Zoological Survey of India, 7: 41-45.

[22] Sharma, H.S., 2007. Freshwater Fishes. In Fauna of Madhya Pradesh (including Chhattisgarh), State Fauna 


\section{International Journal of Science and Research (IJSR) ISSN (Online): 2319-7064 \\ Index Copernicus Value (2015): 78.96 | Impact Factor (2015): 6.391}

Series, 15(1): 147-244 (Published by Director, Zool. Surv. India, Kolkata).

[23] Sharma, H.S., 2008. "Pisces" Faunal diversity of Jabalpur district (M.P.). Zoological Survey of India, pp: 225-274.

[24] Sharma, H.S., 2009. "Pisces" Fauna of Pachmarhi Biosphere Reserve (M.P.), Conservation Area Series, Zoological Survey of India, 39: 135-173.

[25] Dwivedi, R.K., Khan, M.A Singh, H.P., Singh D.N. and Tyagi, R.K., 2000. Production dynamics and fisheries development in Naktara reservoir, Madhya Pradesh, India. Journal of Inland Fisheries Society of India. 32(2): 81-86.

[26] Shukla, A.N., Pandey A. and Shrivastava S., 2008. Observations on fish biodiversity variation in Gambhir Dam Ujjain (M.P.), India, Aquaculture, 4(1): 15-21.

[27] Chandra, Kailash, Sharma, R.M. and Ojha, P.,, 2010. A compendium on the faunal resources of Narmada River Basin in Madhya Pradesh. Rec. zool. Surv. India, Occ. Paper No., 310: 1-152 (Published by the: Director, Zool. Surv. India, Kolkata).

[28] Thilak, J., 2009. "Pisces" Fauna of Bandavgarh Tiger Reserve, Conservation Area Series, 40. Zool. Surv. India, pp: 147-160.
[29] Thilak, J., 2011. On a collection of fishes from Singhori Wildlife Sanctuary, dist. Raisen, M.P. Bionotes, 13(1): 21-22.

[30] Mahor, R.K., 2011. A survey of Fish and Fisheries of the fresh water reservoir Tighra, Gwalior, Madhya Pradesh. International Referred Research Journal, 2: 125.

[31] Solanki, P., Singh. S. Sharmaand I.V. Mathur, R., 2011. Fish Fauna of Sanjay Sagar Reservoir of District Guna (MP). Biological Forum - An International journal, 3(1): 44-45.

[32] Talwar, P.K. and hingran, A.G., 1991. Inland Fishes of India and adjacent countries. Vols. I and II. Oxford and IBH publishing Co. Pvt. Ltd., pp: 1158.

[33] Jayaram, K.C., 1991. Revision of the genus Puntius Hamilton form Indian region, Record of Zoological Survey of India Occasional Paper, 135: 1-178.

[34] Day, F. S., 1958. The fishes of India, William Dawson's and Sons, Ltd. London. 1: 777.

[35] Shrivastava, G., 1998. Fishes of U.P. Bihar, Vishwavidhyalaya Prakashan, Chowk Varanasi, 221001. India Pub. (7).

Table 1: List of Fish species of Tamer River together with abundance and threat status

\begin{tabular}{|c|c|c|c|c|c|c|c|c|}
\hline \multirow{2}{*}{ S. No } & \multirow{2}{*}{ Order } & \multirow{2}{*}{ Family } & \multirow{2}{*}{ Species } & \multirow{2}{*}{$\begin{array}{l}\text { Threat } \\
\text { Status }\end{array}$} & \multirow{2}{*}{$\begin{array}{c}\text { Relative } \\
\text { Abundance }\end{array}$} & \multicolumn{3}{|c|}{ Sampling Site } \\
\hline & & & & & & 1 & 2 & 3 \\
\hline \multirow[t]{2}{*}{1} & \multirow{2}{*}{ Clupiformes } & \multirow[t]{2}{*}{ Notopteridae } & Notopterus notopterus & LR-nt & $\mathrm{M}$ & + & + & + \\
\hline & & & Notopterus chitala & LR-nt & $\mathrm{M}$ & + & + & + \\
\hline \multirow[t]{16}{*}{2} & \multirow[t]{16}{*}{ Cypriniformes } & \multirow[t]{16}{*}{ Cyprinidae } & Catla catla & VU & $\mathrm{M}$ & + & + & + \\
\hline & & & Cirrhinus mrigala & LR-nt & $\mathrm{C}$ & + & + & + \\
\hline & & & Cirrhinus reba & VU & $\mathrm{M}$ & - & + & + \\
\hline & & & Ctenopharyngodon idellus & EX & $\mathrm{C}$ & - & + & + \\
\hline & & & Cyprinus carpio & EX & $\mathrm{A}$ & + & + & + \\
\hline & & & Labeo bata & LR-nt & $\mathrm{M}$ & - & - & + \\
\hline & & & Labeo calbasu & LR-nt & $\mathrm{M}$ & - & + & + \\
\hline & & & Labeo fimbriatus & LR-nt & $\mathrm{M}$ & - & + & + \\
\hline & & & \begin{tabular}{|l} 
Labeo gonius \\
\end{tabular} & LR-nt & $\mathrm{M}$ & - & + & + \\
\hline & & & Labeo rohita & LR-nt & $\mathrm{A}$ & + & + & + \\
\hline & & & Osteobrama cotio & LR-nt & $\mathrm{M}$ & + & + & + \\
\hline & & & Puntius chola & VU & $\mathrm{M}$ & - & - & + \\
\hline & & & Puntius sarana & VU & A & + & + & + \\
\hline & & & Puntius sophore & LR-nt & $\mathrm{C}$ & + & + & + \\
\hline & & & Puntitus ticto & LR-nt & A & + & + & + \\
\hline & & & Tor tor $*$ & EN & $\mathrm{R}$ & + & + & + \\
\hline \multirow[t]{8}{*}{3} & \multirow[t]{8}{*}{ Siluriformes } & \multirow[t]{2}{*}{ Siluridae } & Ompok bimaculatus & $\mathrm{EN}$ & $\mathrm{R}$ & + & + & + \\
\hline & & & Wallago attu & LR-nt & $\mathrm{R}$ & + & + & + \\
\hline & & \multirow[t]{4}{*}{ Bagridae } & Mystus bleekeri & VU & $\mathrm{M}$ & + & + & + \\
\hline & & & Mystus seenghala & $\mathrm{NE}$ & $\mathrm{M}$ & + & + & + \\
\hline & & & Mystus cavasius & LR-nt & M & + & + & + \\
\hline & & & Mystus tengara & $\mathrm{NE}$ & $\mathrm{M}$ & + & + & + \\
\hline & & Clariidae & Clarius batrachus & VU & $\mathrm{M}$ & + & + & + \\
\hline & & Heteropneustidae & Heteropneustes fossilis & VU & $\mathrm{M}$ & + & + & + \\
\hline 4 & Beloniformes & Belonidae & Xenentodon cancila & LR-nt & $\mathrm{R}$ & - & + & + \\
\hline \multirow[t]{3}{*}{5} & \multirow[t]{3}{*}{ Ophiocephaliformes } & \multirow[t]{3}{*}{ Ophiocephalidae } & Channa marulius & LR-nt & $\mathrm{A}$ & + & + & + \\
\hline & & & Channa punctatus & LR-nt & $\mathrm{M}$ & + & + & + \\
\hline & & & Channa striatus & LR-lc & $\mathrm{M}$ & - & - & + \\
\hline \multirow[t]{2}{*}{6} & \multirow[t]{2}{*}{ Perciformes } & Nandidae & Nandus nandus & LR-nt & $\mathrm{M}$ & + & + & + \\
\hline & & Anabantidae & Anabas testudineus & VU & $M$ & - & - & + \\
\hline \multirow[t]{2}{*}{7} & \multirow[t]{2}{*}{ Mastacembeliformes } & \multirow[t]{2}{*}{ Mastacembelidae } & Mastacembelus armatus & $\mathrm{NE}$ & $\mathrm{A}$ & + & + & + \\
\hline & & & \begin{tabular}{|l|} 
Mastacembelus pancalus \\
\end{tabular} & LR-nt & $\mathrm{R}$ & + & + & + \\
\hline
\end{tabular}

1: Site- 1 Near Temar Bridge; 2: Site- 2 Near Temar Fall; 3: Site- 3 Near Saliwara Village; A: Abundant; C: Common; M: Moderate; R: Rare; +: Present; -: Absent; VU: Vulnerable; EN: Endangered; LRnt: Lower Risk near threatened; LRlc: Lower Risk least concern; EX: Exotic; NE: Not Evaluated and *: Recently this spices declared as state Fish of Madhya Pradesh. 